\title{
HYDROCHEMICAL RESPONSE OF CAVE DRIP WATER TO SNOWMELT WATER, A CASE STUDY FROM VELIKA PASICA CAVE, CENTRAL SLOVENIA
}

\author{
SPREMEMBE HIDROKEMIJSKIH LASTNOSTI PRENIKLE VODE \\ V JAMI KOT POSLEDICA DOTOKA SNEŽNICE: PRIMER JAME \\ VELIKA PASICA, OSREDNJA SLOVENIJA
}

\author{
Wei LIU ${ }^{1} \&$ Anton BRANCELJ ${ }^{2}$
}

\begin{abstract}
UDC 556.114:551.44(497.4)

Wei Liu \& Anton Brancelj: Hydrochemical response of cave drip water to snowmelt water, a case study from Velika Pasica Cave, Central Slovenia

A more accurate interpretation of data is required in order to understand the processes of hydrological movement and hydrochemical variation of epikarst water flow. A drip, VP1, from the Velika Pasica Cave (Central Slovenia) was studied during a period which occurred at the end of a long wet, cold winter. The sources for the percolation water in the cave most probably were rain water and snowmelt water, as inferred from the surface hydrological conditions. The discharge was monitored during the study period in one hour intervals. Each hour a water sample from the drip was taken for measurements of electric conductivity and major ions concentrations. Due to the specific climatic condition within the shallow cave, the amount of discharge was the dominant driving force in the hydrochemical variation. The effect of $\mathrm{CO}_{2}$ corrosion and prior calcite precipitation (PCP) was weakened with this condition; the high correlation between $\mathrm{Mg}^{2+}, \mathrm{Ca}^{2+}$ and micro-variation in the $\mathrm{Mg} / \mathrm{Ca}$ ratio indicated the weakened PCP. The low concentration of ions did not respond strongly with the recharge event. On the contrary, the drip water temperature preformed as a good water percolation tracer.

Key words: cave drip water, dilution, epikarst, hydrochemistry, snowmelt water.
\end{abstract}

\begin{abstract}
Izvleček
UDK 556.114:551.44(497.4)

Wei Liu \& Anton Brancelj: Spremembe hidrokemijskih lastnosti prenikle vode $v$ jami kot posledica dotoka snežnice: primer jame Velika Pasica, osrednja Slovenija

$\mathrm{Za}$ razumevanje procesov pretakanja in kemijskih sprememb v prenikajoči vodi v epikraški coni je potrebno bolj natančno zajemanje in interpretacija podatkov. Ob koncu dolge in hladne zime $\mathrm{z}$ obilnimi padavinam je bil $\mathrm{v}$ ta namen podrobneje analiziran curek, VP1, v jami Velika Pasica (osrednja Slovenija). Najverjetnejša vira prenikle vode $\mathrm{v}$ jami sta bila padavinska voda in snežnica, kot je razvidno iz podatkov iz površinskih opazovanj. Pretok curka je bil v času podrobnejših analiz spremljan v enournih intervalih. Vsako uro je bil odvzet tudi vzorec vode za meritve električne prevodnosti ter koncentracij glavnih ionov. Zaradi specifičnih klimatskih pogojev v plitvi kaški jami je bil glavni vzrok za kemijske spremembe pretok prenikle vode. Vplivi korozije zaradi koncentracije $\mathrm{CO}_{2}$ in zaradi predhodnega izločanja kalcita (PCP) so bili v tem primeru zmanjšani; visoka korelacija med $\mathrm{Mg}^{2+}$ in $\mathrm{Ca}^{2+}$ ter le majhne spremembe v razmerju $\mathrm{Mg} / \mathrm{Ca}$ so nakazovale oslabljen vpliv PCP. Nizka vsebnost ionov ni sledila povsem intenzivnosti padavin. $\mathrm{V}$ nasprotju s tem pa je temperatura prenikle vode delovala kot dobro sledilo le-te.

Ključne besede: epikras, hidrokemija, prenikajoča voda, razredčevanje, snežnica.
\end{abstract}

\section{INTRODUCTION}

Higher resolution and accurate data are necessary in order to understand the dynamics of groundwater hy- drochemistry (McDonald et al. 2007; Yang et al. 2012). Most previous works have relied on relative long inter-

\footnotetext{
${ }^{1}$ Wei Liu, Department of Freshwater and Terrestrial Ecosystem Research, National Institute of Biology, Večna pot 111, SI-1000, Ljubljana, Slovenia; phone: +38670344830; E-mail: allen.wei.liu@nib.si

${ }^{2}$ Anton Brancelj, Department of Freshwater and Terrestrial Ecosystem Research, National Institute of Biology, Večna pot 111, SI-1000, Ljubljana, Slovenia; University of Nova Gorica, Vipavska cesta 13, SI-5000 Nova Gorica, Slovenia.
}

Received/Prejeto: 10.07.2013 
vals (Backer et al. 1997; Fairchild et al. 2006) resulting in some important discoveries, but some details may have been overlooked. As the development of high accuracy technology for cave drip water monitoring has been applied to speleological hydrological studies (Fernandez-Cortes et al. 2008; Sheffer et al. 2011; Jex et al. 2012), increasingly details on micro-scales were discovered. Many caves have been monitored in order to interpret and define water flow variations in the vadose zone (Smart \& Friederich 1987; Baldini et al. 2006; Kogovšek \& Petrič 2012), which can elucidate details of hydrochemical processes within the caves (Vokal et al. 1999; Backer et al. 2000; Tooth \& Fairchild 2003; Kogovšek 2011). Additionally, the hydro-chemists endeavoured to interpret the mineral variations of cave drip water spatially and temporally in detail (Baldini et al. 2006). Most research on cave drip water has focused on identifying criteria from the rain infiltration events (Kogovšek 2007). Kogovšek (2010) discussed the flood wave formed by snowmelt water in the vadose zone in the Postojnska jama. However, the fine time interval studies on hydrochemical response to snowmelt water in the epikarst are still rare.

The seasonal aridity and humidity, coldness and warmness significantly affect the chemical composition of karst water (Liu et al. 2007; Yang et al. 2012). Baker et al. (2000) found that the $\mathrm{Mg} / \mathrm{Ca}$ ratio was indicative for relatively dry weather. Furthermore, Fairchild et al. (2006) found the $\mathrm{Mg} / \mathrm{Ca}$ ratio was related to low-flow percolating conditions but it was a non-linear relationship. Zhang et al. (2010) stated that, under dry conditions, $\mathrm{CO}_{2}$ controlled the hydrochemistry of karst water. However, the processes in wet, cold conditions with continuous recharge have not been studied in detail yet.

Numerous mechanisms are driving drip-water hydrochemistry under varying discharge conditions, therefore, single proxies as a means of variability control should be considered. Our objective in this paper is to present the hydrochemical variation of cave drip water after a long, cold, wet winter (with nil, or little biointerference) at a small scale, conducted in the shallow (i.e. epikarstic) Velika Pasica Cave. Under this specific climatic condition, a high-frequency sampling regime for hydrochemical characteristics for drip water was carried out inside the cave, in an attempt to provide a supplementary understanding of epikarst hydrochemical processes. The hypothesis we proposed is that major qualitative changes, in terms of physical and chemical characteristics in rain \& melt water properties, occur in the thin epikarst zone.

\section{STUDY SITE DESCRIPTION}

The study site, Velika Pasica Cave $\left(45^{\circ} 55^{\prime} 14 " \mathrm{~N}\right.$, $14^{\circ} 29^{\prime} 41^{\prime \prime} \mathrm{E}$ ), is near the village Gornji Ig, $20 \mathrm{~km}$ south of Ljubljana (Slovenia). Entrance into the cave is at the elevation of $662 \mathrm{~m}$ a.s.l. (Fig.1, I). The cave formed in the thin bedded Norian-Retian dolomite of the Upper Triassic age with the strata of bedrock dipping north at $10-15^{\circ}$ (Pleničar 1970). Approximately three hundred metres to the southwest, there is a $765 \mathrm{~m}$ hill, which slopes towards to the cave with an inclination of approximately $30^{\circ}$. There is no surface water around the cave, with the exception of a small ephemeral spring (Fig. 1, I) (Brancelj 2002).

The cave is positioned close to the top of the karstic plateau covered with a thin layer of soil, varying from $0-20 \mathrm{~cm}$ in depth. The thickness of the cave ceiling is $10-12 \mathrm{~m}$ at maximum, and only $2-5 \mathrm{~m}$ at minimum. The cave is a $126 \mathrm{~m}$ long horizontal gallery rich in flowstone decorations (Fig. 1, II). The only known entrance is located at the bottom of a $10 \mathrm{~m}$ deep circular depression with a diameter of $15 \mathrm{~m}$ (Brancelj 2002).
Resulting from the position and structure of the cave, all water within the cave is exclusively percolating water, entering the cave as permanent or temporary drips from the ceiling or temporary flows, after heavy rain or intensive snow melt, from the side of the galleries. Four permanent drips, designated as VP1, VP2, VP3, and VP4, are present in the cave (Fig. 1, II). Due to the restriction of the sampling devices, only drip VP1 was monitored for the critical hydrochemical period analysis. At site VP1, the ceiling depth is approximately $8 \mathrm{~m}$. According to the monitoring results, VP1 was the most rapid responding drip with a wide discharge rate from $61 \mathrm{ml} / \mathrm{min}$ to $1350 \mathrm{ml} / \mathrm{min}$ during the period covered by this case study.

The climate of the Ljubljana area has continental characteristics with warm summers and moderately cold winters. Snow is common from December to February; on average there are 48 days with snow cover recorded each winter season (http://www.arso.gov.si/). 


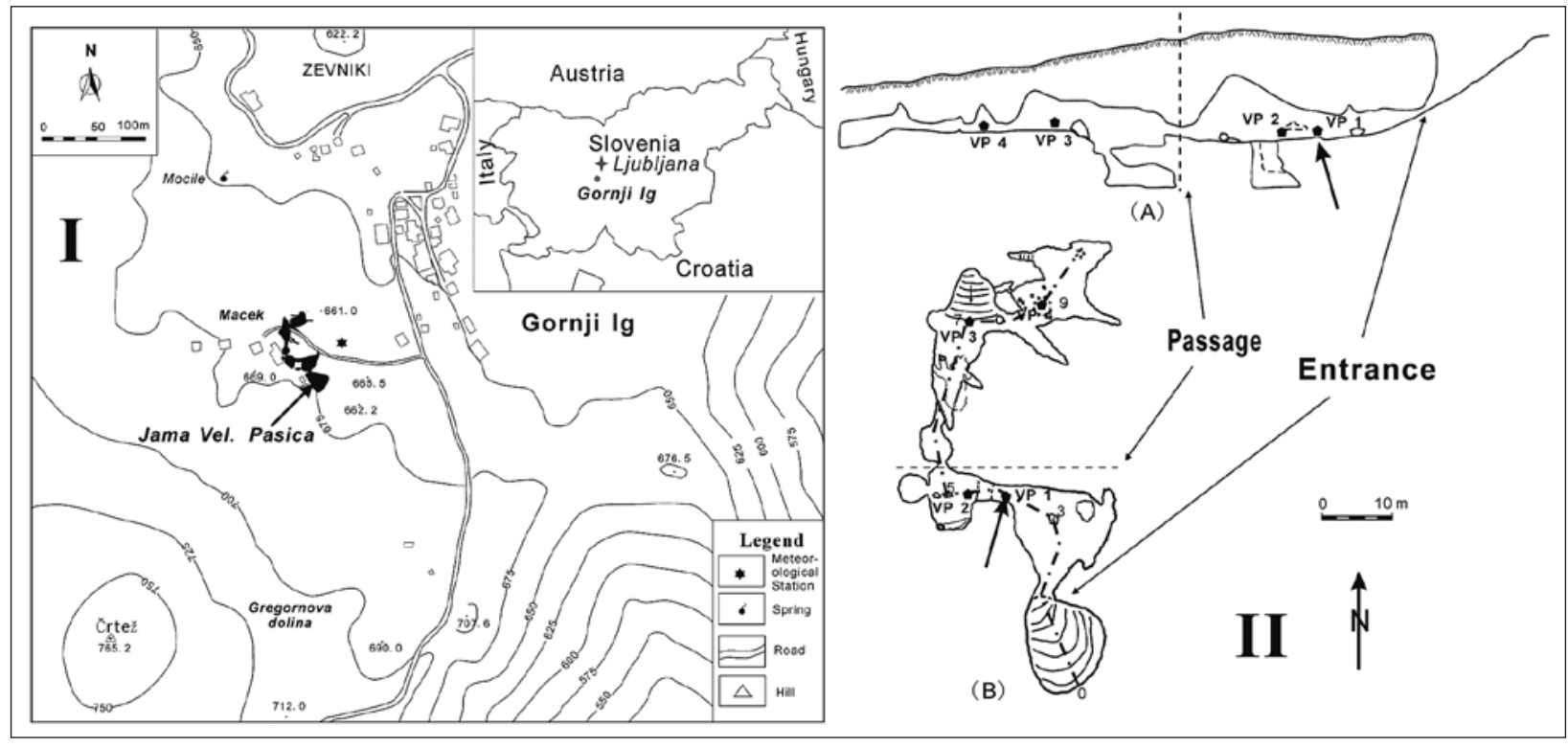

Fig. 1: I (Left): Location of the Velika Pasica Cave (Slovenia). The black figure: the study cave; *: the outside meteorological station; $\Delta:$ the hill Črtež, the highest point of the region; $:$ the spring Močilec, the only surface discharge of the region. II (Right): Cross-section (A) and ground plan (B) of the Velika Pasica Cave (Slovenia). VP1 - VP4: permanent dripping points. The arrowhead points the drip VP1 which is analysed in detail in this article.

\section{MATERIAL AND METHODS}

The samples were collected from $18^{\text {th }}$ to $22^{\text {nd }}$ of March, 2013 , coinciding with the end of the long cold, wet winter with some remnant snow melt (Fig. 2).

The discharge of drip VP1 was monitored in one hour intervals by a rain gauge (RG1-UM-3, Delta-T Device Company) with accuracy and resolution of $\pm 0.2 \mathrm{~mm}$, connected to a data-logger (DL2e, Delta-T Device Company). A plastic screen $(2 \mathrm{~m} \times 2 \mathrm{~m})$ was placed in order to collect dripping water and direct it into the rain gauge funnel. A probe (ST1-05, Delta-T Device Company) (resistivity type; range of measurement of -25 to $+100{ }^{\circ} \mathrm{C}$; digital resolution of $0.1{ }^{\circ} \mathrm{C}$ ) for water temperature was inserted in the lower part of the rain gauge, which also registered readings in one hour intervals. In order to determine the correlation and dissimilarity of temperature between the water at the epikarst discharge point and the drip water near the cave floor, two probes were placed at different places for two weeks, in October 2012. Results showed only a minor difference in water temperature between them.

An automatic water sampler was constructed for sampling in order to monitor the hydrochemical parameters of the drip water, collected as a water sample in a $60 \mathrm{ml}$ PVC bottle each hour. Every $24 \mathrm{~h}$, samples were transported to the laboratory. Electrical conductivity
(EC) and the $\mathrm{pH}$ of the samples were measured immediately after transportation to the laboratory by a Multi $340 \mathrm{i}$ instrument with accuracy \pm 0.01 and a MultiCal pH-540 meter with accuracy \pm 0.01 (WTW Company). Based on the variations of EC, the most typical samples were chosen for ion analysis by ion chromatography (761Compact IC, Methrom) and they included $\mathrm{K}^{+}, \mathrm{Na}^{+}$, $\mathrm{Ca}^{2+}, \mathrm{Mg}^{2+}, \mathrm{SO}_{4}^{2-}, \mathrm{Cl}^{-}$and $\mathrm{NO}_{3}^{-}$ions. Selected samples were stored at $5{ }^{\circ} \mathrm{C}$ in a refrigerator and analysed within 24 hours after collection. Other specific calculations, e.g. $\mathrm{CO}_{2}$ partial pressure $\left(\mathrm{pCO}_{2}\right)$ and saturation index of calcite (SIc) were conducted by a speciation programme PHREEQC (Appelo \& Postma 2005).

A meteorological station was set on the surface near the entrance to the cave in order to record air temperature and precipitation with another data-logger (DL2e, Delta-T Device Company) (Fig. 1, I). The time settings of the outside sensors were tuned with those inside the cave. However, the local meteorological station could not measure the snow depth, thus daily snow depth values were used from a nearby meteorological station - Pokojišče, which is a part of the state meteorological network, located $8.3 \mathrm{~km}$ west of the Velika Pasica Cave, at the elevation of $737 \mathrm{~m}$ a.s.l (http://www. arso.gov.si). 


\section{RESULTS}

The meteorological data on daily precipitation and snow cover thickness from the Pokojišče station were available from the beginning of January till the beginning of April, 2013 (Fig. 2). In total, from January $1^{\text {st }}$ to the March $31^{\text {st }}$, $2013,595.5 \mathrm{~mm}$ of rain fell over 56 days, and $329 \mathrm{~cm}$ of snow in 35 days. In total, there were 63 days with snow cover on the ground. According to the location and the altitude of the Pokojišče station, the data supplied could be supplemented with information from a local meteorological station for the detailed study period from $18^{\text {th }}$ March to $22^{\text {nd }}$ March, as presented in this article (Fig. 3). water accelerated it significantly, as indicated by the increase of drip water discharge. Consequently, the snow melt was controlled by two impacts: the regular daily oscillations of temperature and rain fall, which resulted in two intensive percolation events. The first occurred following an intensive rain event, with rapid and significant response in the drip discharge. The drip started to respond in one hour after the rain event commence, and it rose to its peak at $1250 \mathrm{ml} / \mathrm{min}$ in three hours. The second resulted from a slight rainfall, with a lower, sluggish discharge. It took eight hours for the drip to rise to its

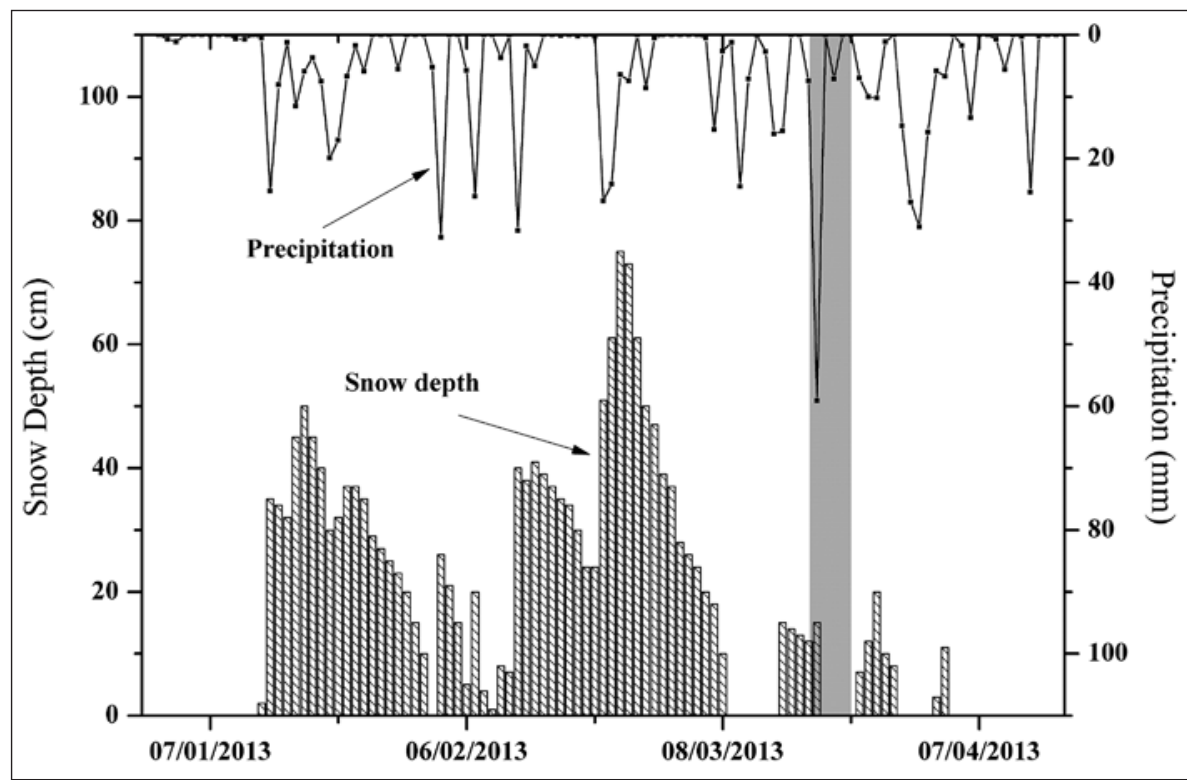

Fig. 2: The daily precipitation and daily snow depth at the Pokojišč meteorological station (SW of Ljubljana, Slovenia) from the beginning of January to the beginning of April, 2013; the grey area is the studied period discussed in this article, detailed in Fig. 3.

There were two rain events during the study period: one was on March $18^{\text {th }}-19^{\text {th }}$, with $41.4 \mathrm{~mm}$ rain falling in 20 hours, and the other one was less intensive, from March $20^{\text {th }}-21^{\text {st }}$, with $7.2 \mathrm{~mm}$ of rain in 14 hours (data from a local meteorological station). The surface temperature maintained the regular daily oscillations with the exception of March $19^{\text {th }}$ when heavy rainfall occurred (Fig.3). Meanwhile, the rate of snow melt followed the surface temperature variation, but the rain peak at $800 \mathrm{ml} / \mathrm{min}$. The warmth of the day temperature melted the snow simultaneously and the rainfall accelerated it significantly to cause the high discharge (Fig. 3).

Consequently, the drip discharge affected the hydrochemical features. The electrical conductivity (EC) represents the concentration of dissolved ions (Tab. 1), showed a reverse variation with the discharge (Fig. 3), but the EC varied sensitively following the discharge, which was also indicated by the high relationship $(r=-0.915$,

Tab. 1: The mean value and variations in chemical composition of the drip water in the Velika Pasica Cave (Slovenia) in a period $18^{\text {th }}$ to $22^{\text {nd }} \mathrm{March}, 2013$ ( $n=19$ ). EC (electrical conductivity); $\mathrm{pCO}_{2}$ (partial pressure of $\mathrm{CO}_{2}$ ); SIc (saturation index of calcite); $\mathrm{Mg} / \mathrm{Ca}$ ( $m o l a r$ ratio between $\mathrm{Mg}^{2+}$ and $\left.\mathrm{Ca}^{2+}\right)$.

\begin{tabular}{|c|c|c|c|c|c|c|c|c|c|c|c|c|c|c|}
\hline Statistic & $\begin{array}{l}E C \\
\mu \mathrm{S} / \mathrm{cm}\left(25^{\circ} \mathrm{C}\right)\end{array}$ & $p H$ & $\begin{array}{l}T \\
\left({ }^{\circ} \mathrm{C}\right)\end{array}$ & $\begin{array}{l}\mathrm{Cl}^{-} \\
(\mathrm{mg} / \mathrm{l})\end{array}$ & $\begin{array}{l}\mathrm{NO}_{3}^{-} \\
(\mathrm{mg} / \mathrm{l})\end{array}$ & $\begin{array}{l}\mathrm{SO}_{4}^{2-} \\
(\mathrm{mg} / \mathrm{l})\end{array}$ & $\begin{array}{l}\mathrm{Na}^{+} \\
(\mathrm{mg} / \mathrm{l})\end{array}$ & $\begin{array}{l}K^{+} \\
(m g / l)\end{array}$ & $\begin{array}{l}\mathrm{Ca}^{2+} \\
(\mathrm{mg} / \mathrm{l})\end{array}$ & $\begin{array}{l}\mathrm{Mg}^{2+} \\
(\mathrm{mg} / \mathrm{l})\end{array}$ & $\begin{array}{l}\mathrm{HCO}_{3}^{-} \\
\left(\mathrm{mg} / \mathrm{l}^{3}\right.\end{array}$ & $\begin{array}{l}p \mathrm{CO}_{2} \\
(\log 10)\end{array}$ & SIc & $\mathrm{Mg} / \mathrm{Ca}$ \\
\hline Mean & 282.53 & 8.3 & 7.07 & 0.15 & 0.31 & 1.21 & 0.50 & 0.21 & 45.92 & 20.60 & 244.34 & -3.00 & 0.60 & 0.75 \\
\hline C.V. & 0.10 & 0.01 & 0.02 & 0.16 & 0.22 & 0.12 & 0.30 & 0.26 & 0.10 & 0.12 & 0.11 & 0.01 & 0.20 & 0.03 \\
\hline Max & 318 & 8.3 & 7.25 & 0.21 & 0.47 & 1.50 & 0.85 & 0.35 & 51.81 & 24.39 & 281.84 & -2.94 & 0.76 & 0.78 \\
\hline Min & 215 & 8.2 & 6.80 & 0.11 & 0.22 & 0.93 & 0.36 & 0.14 & 35.27 & 14.81 & 182.78 & -3.07 & 0.33 & 0.70 \\
\hline
\end{tabular}




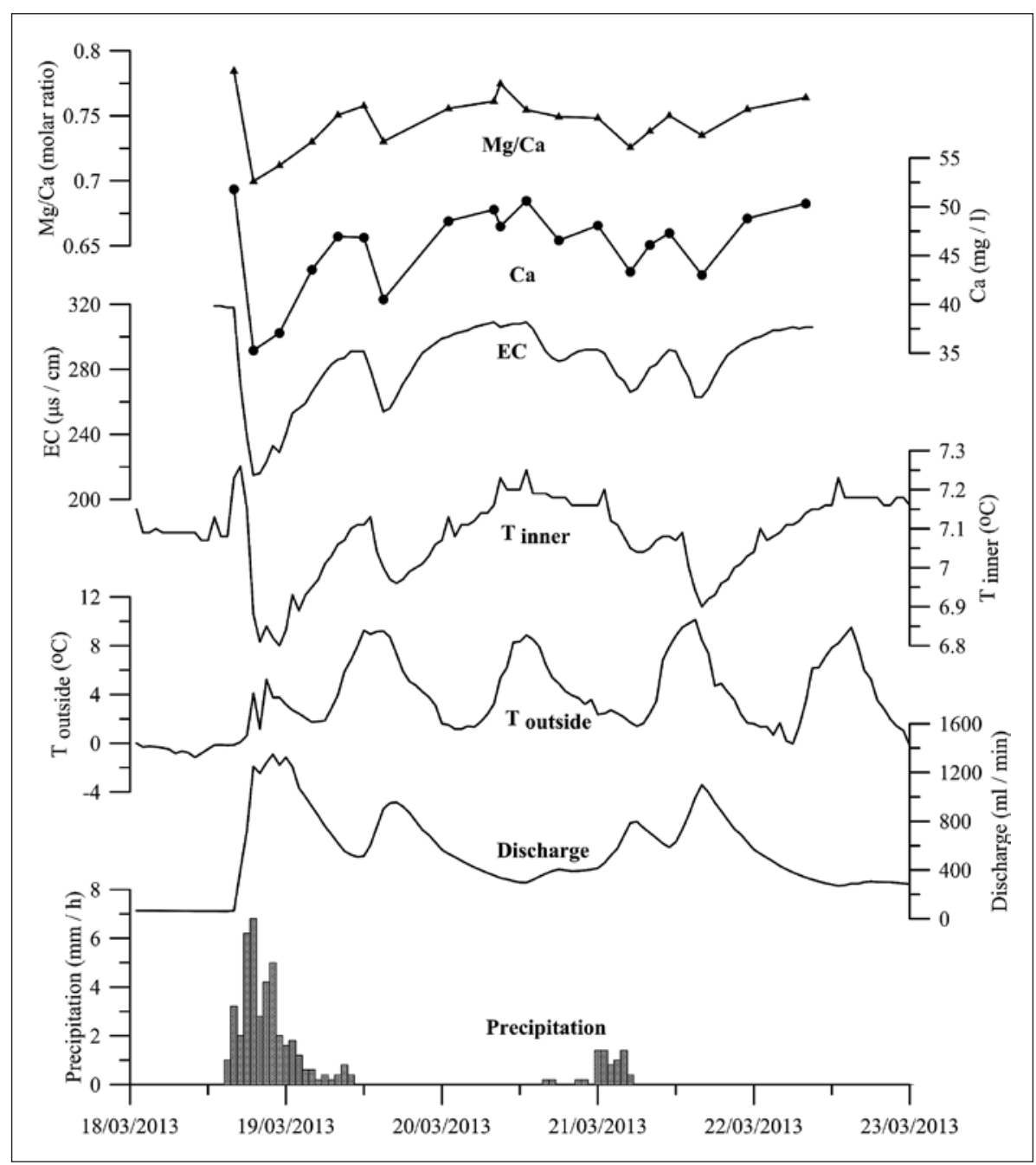

Fig. 3: The hourly variation of the precipitation, the discharge from drip VP1, the surface temperature (T outside), the temperature of drip water (T inner), electric conductivity (EC), $\mathrm{Ca}^{2+}$ concentration and $\mathrm{Mg} / \mathrm{Ca}$ ration of the drip water during the period $18^{\text {th }}$ to $22^{\text {nd }}$ March, 2013.

Tab. 2: The Spearman correlation coefficients of the main hydrological and hydrochemical parameters of the cave drip water: the drip water temperature ( $\left.\mathrm{T}:{ }^{\circ} \mathrm{C}\right)$; discharge of drip water (Q: $\left.\mathrm{ml} / \mathrm{min}\right)$; electric conductivity $(\mathrm{EC}: \mu \mathrm{m} / \mathrm{cm})$; the ions, $\mathrm{Cl}^{-}, \mathrm{NO}_{3}^{-}, \mathrm{SO}_{4}^{2-}, \mathrm{Na}^{+}, \mathrm{K}^{+}$, $\mathrm{Ca}^{2+}, \mathrm{Mg}^{2+}$ and $\mathrm{HCO}_{3}^{-}(\mathrm{mg} / \mathrm{l}), \mathrm{CO}_{2}$ partial pressure $\left(\mathrm{pCO}_{2}\right)$ (log10) and $\mathrm{Mg} / \mathrm{Ca}(\mathrm{m}$ molar ratio) $(n=19)$.

\begin{tabular}{|c|c|c|c|c|c|c|c|c|c|c|c|c|}
\hline & $T$ & $Q$ & $E C$ & $\mathrm{Cl}$ & $\mathrm{NO}_{3}$ & $\mathrm{SO}_{4}$ & $\mathrm{Na}$ & $K$ & $\mathrm{Ca}$ & $M g$ & $\mathrm{HCO}_{3}$ & $p \mathrm{CO}_{2}$ \\
\hline $\mathrm{Q}$ & $-0.976^{* *}$ & & & & & & & & & & & \\
\hline EC & $0.857^{* *}$ & $-0.915^{* *}$ & & & & & & & & & & \\
\hline $\mathrm{Cl}$ & -0.317 & 0.310 & -0.290 & & & & & & & & & \\
\hline $\mathrm{NO}_{3}$ & -0.250 & 0.251 & -0.171 & $0.667^{* *}$ & & & & & & & & \\
\hline $\mathrm{SO}_{4}$ & $0.740^{* *}$ & $-0.799^{* *}$ & $0.885^{* *}$ & 0.066 & 0.132 & & & & & & & \\
\hline $\mathrm{Na}$ & -0.147 & 0.066 & 0.063 & $0.536^{*}$ & $0.575^{* *}$ & 0.208 & & & & & & \\
\hline K & $0.502^{*}$ & $-0.466^{*}$ & 0.392 & $-0.548^{*}$ & $-0.597^{* *}$ & 0.123 & -0.276 & & & & & \\
\hline $\mathrm{Ca}$ & $0.801^{* *}$ & $-0.874^{* *}$ & $0.972^{* *}$ & -0.349 & -0.240 & $0.828^{* *}$ & 0.047 & 0.418 & & & & \\
\hline $\mathrm{Mg}$ & $0.823^{* *}$ & $-0.907^{* *}$ & $0.981^{* *}$ & -0.327 & -0.221 & $0.862^{* *}$ & 0.055 & 0.366 & $0.981^{* *}$ & & & \\
\hline $\mathrm{HCO}_{3}$ & $0.805^{* *}$ & $-0.888^{* *}$ & $0.979^{* *}$ & -0.332 & -0.240 & $0.844^{* *}$ & 0.085 & 0.417 & $0.993^{* *}$ & $0.991^{* *}$ & & \\
\hline $\mathrm{pCO}_{2}$ & 0.193 & -0.214 & 0.365 & 0.036 & 0.227 & $0.466^{*}$ & 0.419 & 0.240 & 0.393 & 0.368 & 0.393 & \\
\hline $\mathrm{Mg} / \mathrm{Ca}$ & $0.762^{* *}$ & $-0.845^{* *}$ & $0.901^{* *}$ & -0.120 & -0.095 & $0.908^{* *}$ & 0.035 & 0.182 & $0.856^{* *}$ & $0.908^{* *}$ & $0.885^{* *}$ & 0.244 \\
\hline
\end{tabular}

*. Correlation is significant at the 0.05 level (2-tailed).

**. Correlation is significant at the 0.01 level (2-tailed). 


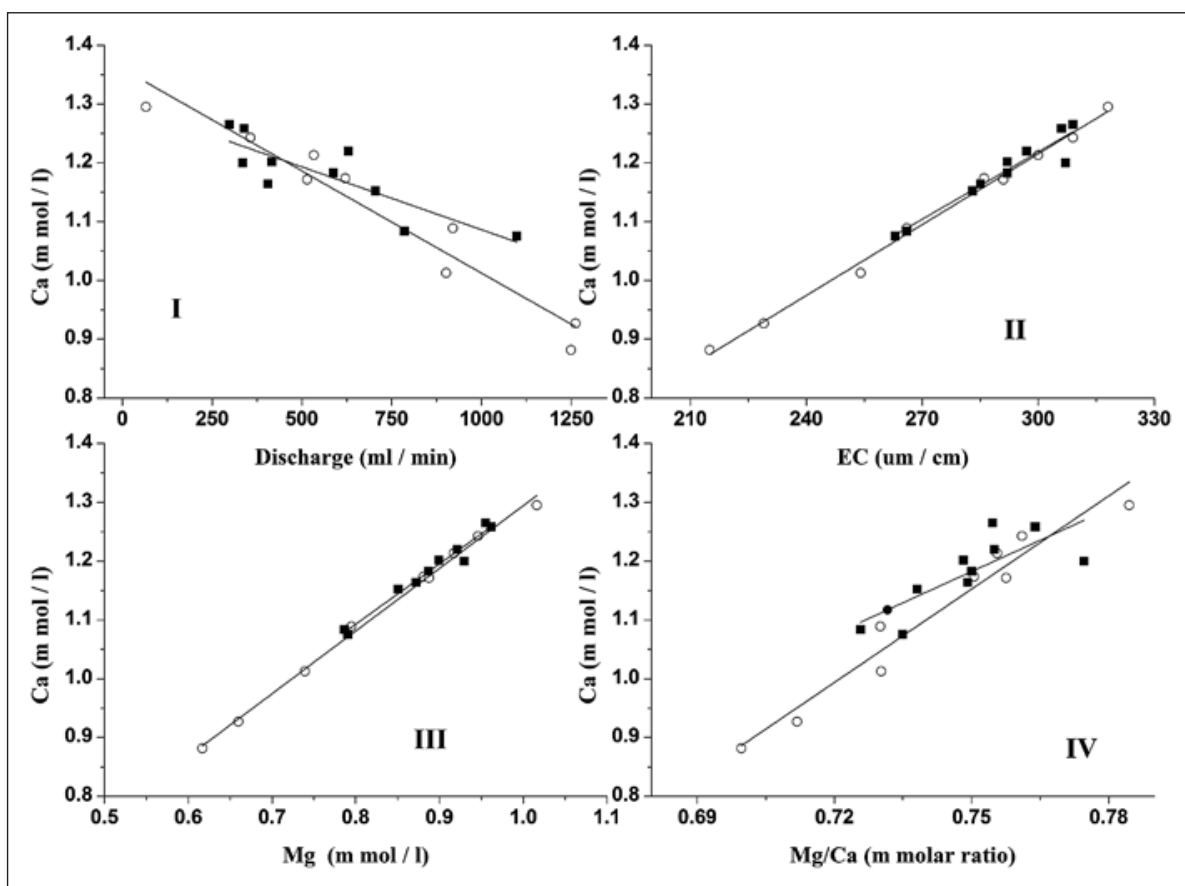

Fig. 4: Cross plots for the main hydrochemical and hydrological parameters of the drip water from the Velika Pasica Cave (Slovenia): (I) $\mathrm{Ca}^{2+}$ ions concentration $v$ s. discharge of drip water; (II) $\mathrm{Ca}^{2+}$ ions concentration vs. electrical conductivity (EC); (III) $\mathrm{Ca}^{2+}$ ions concentration vs. $\mathrm{Mg}^{2+}$ ions concentration); (IV) $\mathrm{Ca}^{2+}$ ions concentration vs. $\mathrm{Mg} / \mathrm{Ca} \mathrm{m}$ molar ratio. The samples were divided into two groups according to two flood events: white circles represented the first flood event and the solid squares represented the second flood event. $\mathrm{p} \leqslant 0.01$, two-tailed) (Tab. 2). The dominant ion species at drip site VP1 were $\mathrm{Ca}^{2+}, \mathrm{Mg}^{2+}$ and bicarbonate $\mathrm{HCO}_{3}^{-}$(Tab. 1). All indicated relatively low variability, with the coefficient of variation $(\mathrm{CV})=10 \%, 12 \%$ and $11 \%$, respectively, compared with the minor ions, such as $\mathrm{Na}^{+}$with $\mathrm{CV}=30 \%, \mathrm{~K}^{+}$with $\mathrm{CV}=26 \%$. The main components, $\mathrm{Ca}^{2+}$ and $\mathrm{Mg}^{2+}$ and the $\mathrm{Mg} / \mathrm{Ca}$ molar ratio, followed the $\mathrm{EC}$ variation pattern closely and they varied according to the discharge variation (Fig. 3). Following the previous high correlation, the variation in $\mathrm{Mg}^{2+}$ and $\mathrm{HCO}_{3}^{-}$did not present in Fig. 3. The $\mathrm{Mg} / \mathrm{Ca}$ molar ratio was relatively stable with a mean molar value of 0.75 and with $\mathrm{CV}=3 \%$ (Tab. 1). Stable ratio between both ions was indicated with a significant correlation between them $(\mathrm{r}=0.981, \mathrm{p} \leqslant 0.01$, two-tailed) (Tab. 2). It was also valid for $\mathrm{Ca}^{2+} v s . \mathrm{Mg} / \mathrm{Ca}$ ratio $(\mathrm{r}=0.856, \mathrm{p} \leqslant 0.01$ two-tailed).

Regarding the minor ions: $\mathrm{K}^{+}, \mathrm{Na}^{+}, \mathrm{SO}_{4}^{2-}, \mathrm{Cl}^{-}$and $\mathrm{NO}_{3}^{-}$, their concentrations were low but their $\mathrm{CVs}$ were higher than in the dominant ions (Tab. 1). Meanwhile they had low correlation coefficient with the discharge and the dominant ions (Tab. 2). As to $\mathrm{pCO}_{2}$, it maintained stability at around $\log \left(\mathrm{pCO}_{2}\right)=-3.00$, with $\mathrm{CV}=1 \%$ (Tab. 1), but it was insignificant in relationship with other parameters, such as, $\mathrm{Ca}^{2+}(\mathrm{r}=0.393)$ (Tab. 2). The drip water temperature preformed as a special indicator for the drip discharge, correlated closely with the discharge rate $(r=-0.976, p \leqslant 0.01$, two-tailed). While its variation range during observed period was quite narrow, with $\mathrm{CV}=2 \%$.

In order to present the different response to the two flood events, samples were divided into two groups (Fig. 4). The variations of the main hydrochemical and hydrological parameters of the drip water presented similar and strong correlation between each other during this two events, e.g. in Fig. 4, II, the fitting lines of the two events between $\mathrm{Ca}^{2+}$ and EC overlapped. However, variation ranges for the parameters of the first flood event were larger than those of the second flood, which indicated that the higher discharge caused a lower ion concentration and the slow flow higher concentration. The higher discharge values of the first flood corresponded to the lower $\mathrm{Ca}^{2+}, \mathrm{EC}, \mathrm{Mg}^{2+}$ and $\mathrm{Mg} / \mathrm{Ca}$ values (Fig. 4).

\section{DISCUSSION}

High heterogeneous and complex structure and void topology, epikarst reflects the large parameter for variability and uncertainty in the complicated hydraulic, mechanical, thermal, and chemical processes (Fairchild
\& Baker 2012). A study of a small discharge point from the epikarst could provide the details of local variation. Test site Sinji Vrh, a shallow artificial tunnel, located at in the western part of Slovenia was used to study the water 
flow and solute transport in the unsaturated zone (Trček 2005). In this study, the Velika Pasica Cave, a small cave, located in the thick dolomitized epikarst zone, preformed as a natural discharge point for epikarst hydrochemical and hydrological research.

In order to further simplify the impact factors on the epikarst processes, the study period was chosen at the end of a long, cold and wet winter. During this time, there were two most probably sources for water replenishment to the drip water: snowmelt water and rain water. The day time warmth melted the surface snow cover, and the rainfall accelerated the melting. Thereafter, both converged and percolated down together, thus the two floods in the drip water discharge represented the superposition of these two signals. Additionally, when the rainfall ceased, the drip water discharge mainly represented the snow melt combined with the epikarst storage.

In order to achieve a better understanding of various karst processes, variations in the concentration of ions should be studied with other hydrochemical parameters (McDonald et al. 2007). During the specific study period, the low temperature and high humidity, accompanying the Mediterranean wet winter, weakened evaporation at the site. Meanwhile, due to this environmental condition, the respiration of the bio-activities from plant roots and soil microbes was weakened, as indicated by the $\mathrm{CO}_{2}$ partial pressure in the drip water $\left(\mathrm{pCO}_{2}\right)$ with low value $($ mean $=-3.00)$ and low variation $(\mathrm{CV}=1 \%)$ (Tab. 1), although the $\mathrm{CO}_{2}$ was the main driving force for the dissolution and precipitation of carbonate (Atkin et al. 2000; Liu et al. 2007), and the $\mathrm{pCO}_{2}$ is generally higher in summer (Atkin et al. 2000). Liu et al. (2007) presented the yearly cyclical variation of those parameters which were higher in summer and lower in winter. Additionally, the entrance was the only detected outlet for the Velika Pasica Cave, thus the $\mathrm{CO}_{2}$ exchanging from ventilation was insignificant here, which differs from situations in other caves (Tooth et al. 2003; Spötl et al. 2005).

The water percolated into the cave preformed a primary driving force for most variations recorded during the winter in the cave, in particular, for the cave water hydrochemical composition (Fig. 2). EC was an indicator of the amount of ions in solution. According to the ion analysis, $\mathrm{Ca}^{2+}, \mathrm{Mg}^{2+}$ and $\mathrm{HCO}_{3}^{-}$were the dominant ions in drip water. The variation of $\mathrm{EC}$ was highly negatively related to the discharge as well as the dominant ions (Fig. 3, Tab. 2). EC normally deceased after rainfall, and showed inverse variation with the discharge. While the strong correlation between the EC and discharge indicated that the intensity of the floods mainly controlled the hydrochemical variation by the mixing fresh infiltrated water (rain and snow) with stored water in vadose zone (i.e. the water stored in epikarst), which was differed from the summer time situation (Liu et al. 2007), as other factors also have significant impact during that season. Due to the dual-medium systems within epikarst (Akinson et al. 1977; Liedl et al. 2003), which are characteristic for the widespread fracture-net storage system and the well-developed fracture-net rapid discharge system (conduits), the intensive recharge could be discharged rapidly as considerably diluted drip water (Baldini et al. 2006; Fairchild \& Baker 2012). The two different intensive flood events described here clearly indicated that the degree of dilution or mixing relied on the amount of recharge and the higher discharge correlates with the lower ion concentration (Fig. 4). When the fast flow cased, the stored water was dominate in the discharge, which corresponded with the increase of EC and the dominant ions concentration.

Baker et al. (2000) discussed that water/soil and water/ rock contact times, variable degrees of dilution and the prior calcite precipitation (PCP) in the vadose zone also controlled the calcium dissolution processes, as well as the replenishment from multiple reservoirs (McDonald et al. 2007). However, in this case study, $\mathrm{Ca}^{2+}$ and $\mathrm{Mg}^{2+}$ have a similar variation to the $\mathrm{Mg} / \mathrm{Ca}$ ratio (Figs. $3 \& 4$ ), indicated by the high correlation coefficients (Tab. 2), which is not exactly similar in comparison with other caves (Baldini et al. 2006; Fairchild et al. 2006). Within recent years, the ratio of $\mathrm{Mg} / \mathrm{Ca}$ in cave drip waters has acted as a good indicator of the climatic condition (Huang et al. 2001). The ratio in the Velika Pasica Cave was quite stable at 0.75 , almost as a constant (with $\mathrm{CV}=3 \%$ ), which indicated that the parent rock was not pure dolomite and both ions were not precipitated after they dissolved, such as the PCP. In the discussion above, the low $\mathrm{pCO}_{2}$ resulted in the low carbonate dissolution and the wet weather continued to replenish the stored water with the fresh infiltrated water (rain and snow). Thus, the resident time of stored water might not be long enough to accumulate a high $\mathrm{Ca}^{2+}$ concentration for PCP at the drip VP1 in a simple recharge system.

Apart of $\mathrm{Ca}^{2+}$ and $\mathrm{Mg}^{2+}$ ions, other dissolved ions also played important role in the studies on mixing processes of drip water in the unsaturated zone above the cave (Huang et al. 2001; Tooth \& Fairchild 2003; Fairchild et al. 2006). However, excepting $\mathrm{SO}_{4}^{2-}$, most of these ions had low concentrations (Tab. 1) and low correlation with the discharge (Tab. 2), which means they were not significantly affected by the percolation events. Origin of the rather high concentration of $\mathrm{SO}_{4}^{2-}$ ions might be from the dissolution of gypsum $\left(\mathrm{CaSO}_{4}\right)$ in the parent rock. 
The temperature of the drip water presented high correlation and consistency with the discharge (Tab. 2), which also indicated the short resident time of the water.
Therefore, the temperature of the drip water could act as an efficient tracer for the epikarst flow under such conditions (Anderson 2005).

\section{CONCLUSION}

In order to interpret geochemical processes during the snow melt period in the epikarst, high-frequency sample collection and chemical monitoring on cave drip water was carried out at Velika Pasica Cave (Central Slovenia). This study reveals that the major qualitative transformation between rain and dripping water in a sense of chemical and physical properties happened in a thin epikarst layer, which extends few meters in depth. The study period occurred at the end of a long, cold, wet winter. The main replenishment for the cave drip water was rain fall and snowmelt water. Under this special condition, some conclusions could be presented as: 1) After a long cold and wet period, the water percolated into the cave was performed a primary driving force for water hydrochemical variations in the cave during the winter, which performed as the dilution effect or mixing of the fresh and stored water in vadose zone; 2) The effect of $\mathrm{CO}_{2}$ corrosion and PCP was weakened during this condition; 3) The main ion composition $\left(\mathrm{Mg}^{2+}\right.$ and $\left.\mathrm{Ca}^{2+}\right)$ presented high correlation with $\mathrm{Mg} / \mathrm{Ca}$ ratio and the drip water discharge, indicated the weakened PCP; 4) The variation of low concentration ions had lower correlation with the discharge, as they did not strongly respond with the recharge event. On the contrary, the drip water temperature preformed as a good tracer on short term (within few hours).

The research revealed more detailed and accurate results from the high-frequency monitoring over a specific period, which confirmed and deepened the previous work on cave drip water. However, long-term monitoring should be continued for interpretation of the seasonal hydrochemical variation and climate change.

\section{ACKNOWLEDGEMENTS}

Authors would like to extend thanks to colleagues from the National Institute of Biology who contributed to field work, in collecting data and maintaining instruments. This research was founded by the Slovenian Research Agency (ARRS) within the program P1-0255 (Structure, function and communications in ecosystems) and within the Program for Young Researchers (Contract no. 1000-11-310196). We also extend our thanks to Professor Julia Ellis Burnet for linguistic corrections and two anonymous reviewers for their valuable comments and corrections on a previous version of the text.

\section{REFERENCES}

Anderson, M. P., 2005: Heat as a ground water tracer.Ground water, 43, 6, 951-968.

Appelo, C.A.J. \& D. Postma, 2005: Geochemistry, Groundwater and Pollution.- Balkema Publishers, pp.649, Leiden, The Netherlands.

Atkin, O.K., Edwards, E.J. \& B.R. Loverys, 2000: Response of root respiration to changes in temperature and its relevance to global warming.- New Phytologist, 147, 141-154.
Atkinson, T.C., 1977: Diffuse flow and conduit flow in limestone terrain in the Mendip Hills, Somerset (Great Britain).- Journal of Hydrology, 35, 93-110.

Baker, A., Barnes, W.L. \& P.L. Smart, 1997: Variations in the discharge and organic matter of stalagmite drip waters in Lower Cave, Bristol.- Hydrological Processes, 11, 1541-1555. 
Baker, A. \& Genty, D. \& I.J. Fairchild, 2000: Hydrological characterization of stalagmite drip waters at Grotte de Villars, Dordogne, by the analysis of inorganic species and luminescent organic matter.- Hydrology and Earth System Sciences, 4, 3, 439-449.

Baldini, J.U.L., McDermott, F. \& I.J. Fairchild, 2006: Spatial variability in cave drip water hydrochemistry: implications for stalagmite paleoclimate records.Chemical Geology, 235, 3-4, 390-404.

Brancelj, A., 2002: Microdistribution and high diversity of Copepoda (Crustacea) in a small cave in central Slovenia.- Hydrobiology, 477, 59-72.

Fairchild, I.J., Tuckwell, G.W., Baker, A. \& A. F. Tooth, 2006: Modelling of drip water hydrology and hydrochemistry in a weakly karstified aquifer (Bath, UK): implications for climate change studies.- Journal of Hydrology, 321, 1-4, 213-231.

Fairchild, I.J. \& A. Baker, 2012: Speleothem science: from process to past environments.- Willey Blackwell, pp. 432, Oxford.

Fernandez-Cortes, A., Calaforra, J.M. \& F. Snchez-Martos, 2008: Hydrogeochemical processes as environmental indicators in drip water: Study of the Cueva del Agua (Southern Spain).- International Journal of Speleology, 37, 1, 41-52.

Huang, Y., Fairchild, I.J., Borsato, A., Frisia, S., Cassidy, N.J., McDermott. F. \& C.J. Hawkesworth, 2001: Seasonal variations in $\mathrm{Sr}, \mathrm{Mg}$ and $\mathrm{P}$ in modern speleothems (Grotta di Ernesto, Italy).- Chemical Geology, 175, 3-4, 429-448.

Jex, C.N., Mariethoz, G., Baker, A., Graham, P., Andersen, M.S., Acworth, I., Edwards, N. \& C. Azcurra, 2012: Spatially dense drip hydrological monitoring and infiltration behaviour at the Wellington Caves, South East Australia.- International Journal of Speleology, 41, 2, 283-296.

Kogovšek, J., 2007: Rainwater percolation dynamics assessment through the vadose karst zone on the basis of discharge measurements.- Acta Carsologica, 36, 2, 245-254.

Kogovšek, J., 2010: Characteristics of percolation through the karst vadose zone. -ZRC Publishing, pp.168, Ljubljana.

Kogovšek, J., 2011: Impact of chlorides, nitrates, sulfates and phosphates on increased limestone dissolution in the karst vadose zone (Postojna Cave, Slovenia).Acta Carsologica, 40, 2, 319-327.
Kogovšek J. \& M. Petrič, 2012: Characterization of the vadose flow and its influence on the functioning of karst springs: Case study of the karst system near Postojna, Slovenia.- Acta carsologica, 41, 1, 101-113.

Liedl, R., Sauter, M., Huckinghaus, D., Clemens, T. \& G. Teutsch, 2003: Simulation of the development of karst aquifers using a coupled continuum pipe flow model.- Water Resources Research, 39, 3, $1057-$ 1062.

Liu, Z.H., Li,Q., Sun, H.L. \& J.L. Wang, 2007: Seasonal, diurnal and storm-scale hydrochemical variations of typical epikarst springs in subtropical karst areas of SW China: soil $\mathrm{CO}_{2}$ and dilution effects.- Journal of Hydrology, 337, 1-2, 207-223.

McDonald, J., Drysdale,R., Hill,D., Chisari, R. \& H. Wong, 2007: The hydrochemical response of cave drip waters to sub-annual and inter annual climate variability, Wombeyan Caves, SE Australia.- Chemical geology, 244, 605-623.

Pleničar, M., 1970: Tolmač k Osnovni geološki karti SFRJ, List Postojna. Zvezni geološki zavod Beograd. (= Basic geological survey; section Postojna), 62.

Sheffer N.A., Cohen, M., Morin, E., Grodek, T., Gimburg, A., Magal, E., Gvirtzman, H., Nied, M., Isele, D. \& A. Frumkin, 2011: Integrated cave drip monitoring for epikarst recharge estimation in a dry Mediterranean area, Sif Cave, Israel.- Hydrological Processes, 25, 2837-2845.

Smart P.L. \& H. Friederich, 1987: Water movement and storage in the unsaturated zone of a maturely karstified carbonate aquifer, Mendip Hills, England.- In: Proceedings of environmental problems in karst terranes and their solutions conference, $28^{\text {th }}-30^{\text {th }}$, October 1986, Bowling Green, Kentucky. 57-87, KY, USA.

Spötl, C., Fairchild, I.J. \& A. F. Tooth, 2005: Cave air control on drip water geochemistry, Obir Caves (Austria): Implications for speleothem deposition in dynamically ventilated caves.- Geochimica et Cosmochimica Acta, 69, 10, 2451-2468.

Tooth, A.F. \& I.J. Fairchild, 2003: Soil and karst hydrological controls on the chemical evolution of speleothem-forming drip waters, Crag Cave, southwest Ireland. -Journal of Hydrology, 273, 1-4, 51-68.

Trček, B., 2005: The use of natural tracers in the study of the unsaturated zone of a karst aquifer.- Geologija, $48,1,141-152$.

Vokal, B., Obelič, B., Genty, D. \& I. Kobal, 1999: Chemistry measurements of dripping water in Postojna Cave.- Acta Carsologica, 28, 1, 305-320. 
Yang, R., Liu Z.H., Cheng, Z.C. \& M. Zhao, 2012: Response of epikarst hydrochemical changes to soil $\mathrm{CO}_{2}$ and weather conditions at Chenqi, Puding, SW China.- Journal of Hydrology, 468-469, 151-158.
Zhang, C., Yan, J., Pei, J.G. \& Y.J. Jiang, 2010: Hydrochemical variations of epikarst springs in vertical climate zones: a case study in Jinfo Mountain National Nature Reserve of China.- Environmental Earth Sciences, 63, 2, 375-381. Doi: 10.1007/ s12665-010-0708-y. 